we may find a cheap-to-implement accord, acceptable to the United States, the European Union and poorer nations, that actually tackles radiative warming now, within a few decades.

Noah's rainbow was a covenant for all living species, not just humanity. Humanity's emissions now wilfully block the infrared part of that promise. If our nations corrupt the rainbow, is it time to search out supplies of gopher wood and start collecting eukaryotes two-by-two, trying to keep our genetic company afloat while the greedy world goes into liquidation? In the meantime, Snowball Earth makes good spring reading. And when you are done, pass it on to any handy teenager, who will be enthralled, if not by the science, then by the storytelling.

Euan Nisbet is in the Atmospheric Group,

Department of Geology, Royal Holloway,

University of London, Egham,

Surrey TW20 OEX, UK

\section{Gould and God}

\section{A Devil's Chaplain}

by Richard Dawkins,

edited by Latha Menon

Weidenfeld \& Nicolson: 2003. 320 pp.

$£ 16.99$

\section{Jerry A. Coyne}

The original 'Devil's chaplain' was Robert Taylor, an apostate priest and self-styled 'infidel missionary' whose rabble-rousing entourage stormed into Cambridge in 1829 - halfway through Charles Darwin's undergraduate career. Taylor's brew of atheism and republicanism held no allure for young Darwin, then a conventional Christian thoroughly steeped in the hierarchical values of nineteenth-century Britain. But Darwin never forgot Taylor's nickname. In 1856, pondering the brutal inefficiency of natural selection, Darwin wrote to his friend Joseph Hooker: "What a book a devil's chaplain might write on the clumsy, wasteful, blundering, low and horribly cruel works of nature!" Although creationists constantly remind us that On the Origin of Species is a satanic work, Darwin never aspired to succeed Taylor: he was too shy of controversy, too worried about the happiness of his devout wife.

Richard Dawkins, however, is more than happy to step into Taylor's shoes. Religion, writes Dawkins, is a "malignant infection" of the human mind. Six of the 32 essays in this eclectic collection (culled largely from the British press) address religion either directly or indirectly, a surprising statistic for a science writer whose chair at Oxford University is dedicated to the public understanding of science. However, another six essays attack further impassable routes to knowledge (such as homoeopathy, crystal worship and postmodernism). Clearly, Dawkins sees his brief as not only popularizing science, but demolishing its competitors.

Dawkins' other major bugbear - and the main non-divine theme of $A$ Devil's Chaplain - is the late Stephen Jay Gould. Dawkins offers here a gracious tribute to Gould, but also turns his incisive analytical mind and lucid prose against Gould's ideas with devastating effect. For example, Gould's notion that the evolutionary processes that shaped the early history of life (with new phyla being produced) differ qualita-

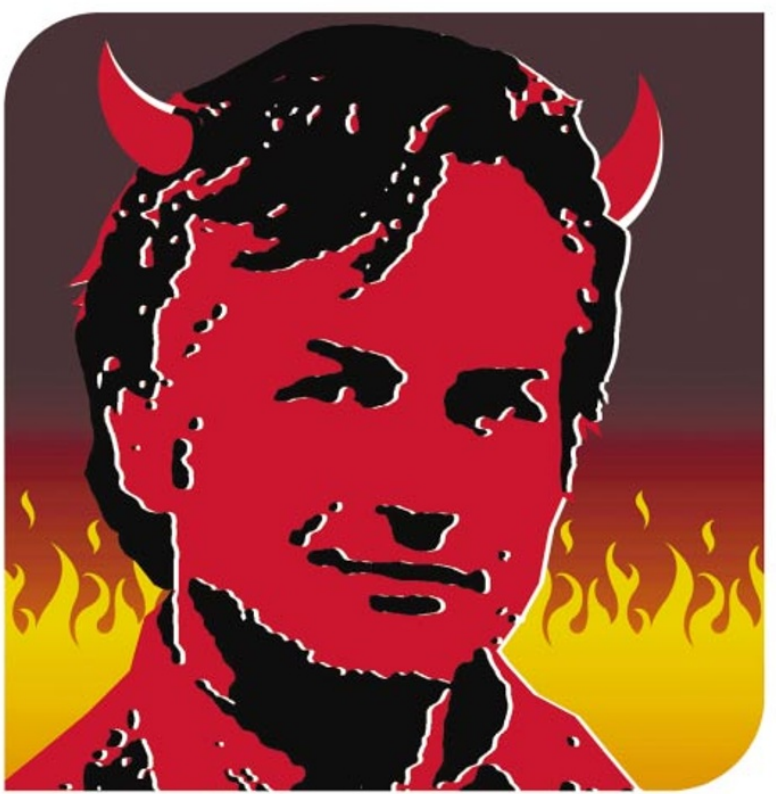
tively from the processes that direct more recent evolution (with only lower-level taxa appearing) is deflated in two deft sentences: "It is though a gardener looked at an old oak tree and remarked wonderingly: 'Isn't it strange that no major boughs have appeared on this tree recently. These days, all the new growth appears to be at the twiglevel!'."

In fact, the critiques of Gould and God are not as unrelated as they appear. As this collection makes clear, Dawkins is a fierce advocate of scientism, the philosophy that genuine truths - as opposed to spiritual or personal 'truths' that are not universally held - can be found only through the scientific method. Gould was not as strict: he was an accommodationist, insisting in works such as Rocks of Ages that both religion and science are independent and valid domains of enquiry. Dawkins, then, is both scientifically and philosophically opposed to Gould. Several books have been written about the scientific arguments between Gould and Dawkins, but Dawkins aficionados outside Britain have had little exposure to his withering assaults on religion, pseudoscience and accommodationism. It's a rare treat to see him sail into battle, prose and logic perfectly attuned to the destructive business at hand. I should add that A Devil's Chaplain is not wholly focused on religion and Gould: it also includes obituaries of friends, and essays on ethics, genetic determinism, Africa (Dawkins spent much of his childhood in Kenya) and meme theory (the collection's only low point, given my view that 'mimetics' is an extended tautology that has yielded no real understanding of human culture). But it's in religious territory that A Devil's Chaplain is most compelling.

"Modern theists," writes Dawkins, "might acknowledge that, when it comes to
Baal and the Golden Calf, Thor and Wotan, Poseidon and Apollo, Mithras and Ammon $\mathrm{Ra}$, they are actually atheists. We are all atheists about most of the gods that humanity has ever believed in. Some of us just go one god further." But Dawkins goes beyond a mere defence of atheism. He also subscribes to the American writer H. L. Mencken's dictum that: "We must respect the other fellow's religion, but only in the sense and to the extent that we respect his theory that his wife is beautiful and his children smart." Why, asks Dawkins, should the public give religious arguments any more credibility than arguments for other brands of nonscientific 'truth'? Curiously, Dawkins does not explore why religious ideas get undue respect. Surely one reason is that arguing about religion (especially when one participant is an atheist) is unproductive, likely to produce only mutual dislike. No rapprochement is possible between those whose beliefs derive from evidence and those whose beliefs either do not depend on evidence or are unshaken by contrary evidence. This is why science and religion are incompatible ways of viewing the world.

Dawkins' critique of religion rests on three points. First, because different faiths make very different claims about the world, they cannot all be true; and none of the claims (such as the bodily assumption of Mary into heaven) can be scientifically verified. Second, the choice among faiths is not based on rational consideration: the vast majority of people simply practice the religion of their parents. This is especially galling to Dawkins, who sees the easy indoctrination of children as a product of natural selection favouring the rapid spread of information between generations. Finally, Dawkins considers religions to be vehicles of evil because they facilitate the labelling 
of people as either 'us' or 'them', fostering xenophobia and its attendant horrors Northern Ireland and the Middle East come to mind.

These views are summarized in a wonderfully passionate essay, "Time To Stand Up", written shortly after 11 September, 2001. One excerpt: "To label people as death-deserving enemies because of disagreements about real-world politics is bad enough. To do the same for disagreements about a delusional world inhabited by archangels, demons, and imaginary friends is ludicrously tragic."

Would that there were an afterlife, so that Robert Taylor could smile upon his far more effective heir! As Taylor and his fellow freethinkers knew, atheism in early nineteenth-century Britain was blasphemy and thus illegal: Taylor was twice jailed for his activities. Thankfully, such strictures are now much rarer, but a subtler form of repression prevails in places such as the United States. Scientist-atheists, bowing to prevalent notions of politically correct social inclusiveness, are unwilling to express their opinions for fear of offending religious sensibilities. But Dawkins makes a strong case that most religions are insidious and dangerous illusions. It's time for those who agree to stand up beside him.

Jerry A. Coyne is in the Department of Ecology and Evolution, University of Chicago, 1101 E. 57 Street, Chicago, Illinois 60637, USA.

\section{............... The writing on the slate}

\section{Nature via Nurture: Genes, Experience and What Makes Us Human \\ by Matt Ridley \\ Fourth Estate: 2003.320 pp. 118.99 \\ HarperCollins: 2003. \$25.95}

\section{Andrew Berry}

Is who we are determined ineluctably by our biological inheritance or, more malleably, by our experience? The debate is surely as old as human consciousness. In 1874 Francis Galton gave it its modern identity when, borrowing from Shakespeare's villain Caliban, "a devil, a born devil, on whose nature nurture can never stick", he cast the issue in terms of what he called a "convenient jingle of words": nature and nurture.

Having made the distinction, in Hereditary Genius Galton then set the tone for the debate to come by hewing dogmatically to an extreme position: "I have no patience with the hypothesis occasionally expressed, and often implied, especially in tales written to teach children to be good, that babies are born pretty much alike, and that the sole agencies in creating differences between boy and boy, and man and man, are steady application and moral effort. It is in the most unqualified manner that I object to pretensions of natural equality."

The other extreme has also attracted its own inflexible adherents, most notably members of the 'behaviourist' school founded by J. B. Watson, whom Ridley quotes: "Give me a dozen healthy infants, wellformed, and my own specified world to bring them up in and I'll guarantee to take any one at random and train him to become any type of specialist I might select: doctor, lawyer, artist, merchant-chief, and yes, even beggar-man and thief, regardless of his talents, penchants, tendencies, abilities, vocations, and race of his ancestors."

This polarization remains with us to this day: the debate is typically couched in terms of nature versus nurture, implying that these factors are mutually exclusive. The issue is clouded by the difficulty of bringing conclusive evidence to bear. Experiments on humans are impracticable or unethical, although the Moghul emperor Akbar, unfettered by regulations on the use of human experimental subjects, did apparently raise several individuals in total isolation to determine which religion - Hinduism, Islam or Christianity — they would spontaneously embrace. The experiment was inconclusive: the lack of stimulation during their development turned Akbar's unfortunate human guinea-pigs into deaf mutes.

Modern commentators have struggled to extricate themselves from the straitjacket of Galton's dichotomy. Some genes do indeed act independently of the environment: regardless of my lifestyle or where I live, I will inevitably develop Huntington's disease if I carry the diseasecausing mutation. And conversely, plenty of our behaviour is largely environmentally determined - that I speak English, not Turkish, is simply a reflection of where I was raised and by whom. But not all behaviour resides at one or other end of the spectrum: genes and the environment often interact such that the either/or categorization of the 'versus' view is misleading.

However, as the evolutionary biologist David Sloan Wilson pointed out in the New York Times on 25 February 2003, the rhetorical allure of the extremes remains strong: "Everyone calls themselves an interactionist. Yet often, when you scratch below the surface, you find a sociobiologist who marginalizes the importance of culture, or a social constructivist who hates the very idea of sociobiology, and they end up painting caricatures of each other. True integrative thinking is in the very early stages."

Nature via Nurture is a book-length exercise in 'integrative thinking': science writer Matt Ridley has produced a paean to interaction that will do much to erode the mutually exclusive view of nature and nurture.

Interaction is best exemplified in a simple idea that typically makes an appearance somewhere near the beginning of a genetics textbook and is then ignored throughout the rest of the book: the outcome produced by a gene may depend upon the context in which the gene is expressed. Citing new work by Darlene Francis at Emory University in Atlanta, Ridley provides an extraordinary and elegant example. C57 and BALB strains of mice differ discretely in some aspects of adult behaviour. But C57 embryos transplanted to BALB uteri and raised by BALB mothers display, as adults, aspects of BALB behaviour; mere cross-fostering (C57 to BALB parent) after birth, however, does not provoke the change, implying that the uterine environment is the critical context. The C57 genotype expresses
C57-typical C57-typical

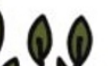

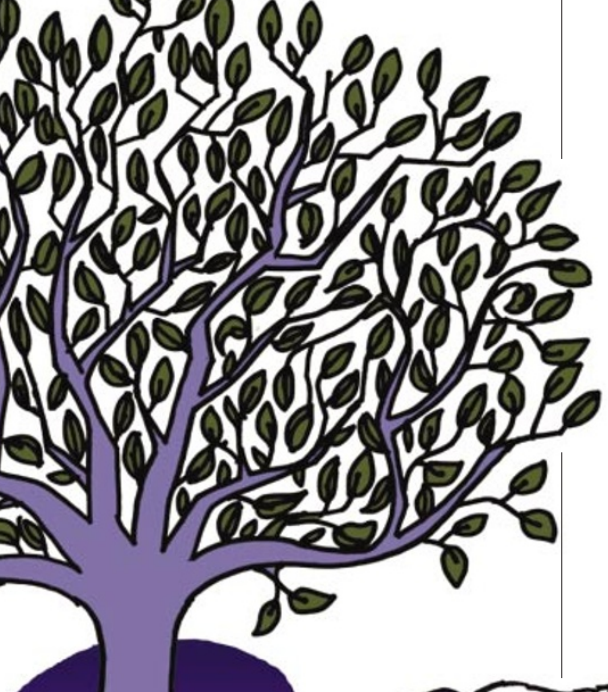

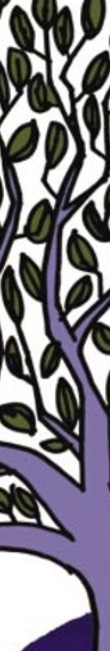

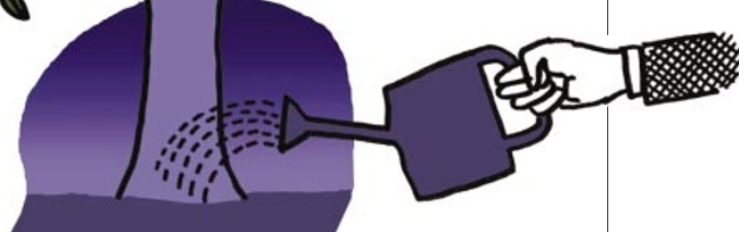

